\title{
PEMBERIAN SANKSI ADAT KEPADA PELAKU PENCURIAN PRATIMA DI BALI
}

\author{
Pande Made Kresna Wijaya1
}

${ }^{1}$ Fakultas Hukum Universitas Udayana, E-mail: pandemadekresnawijaya@gmail.com

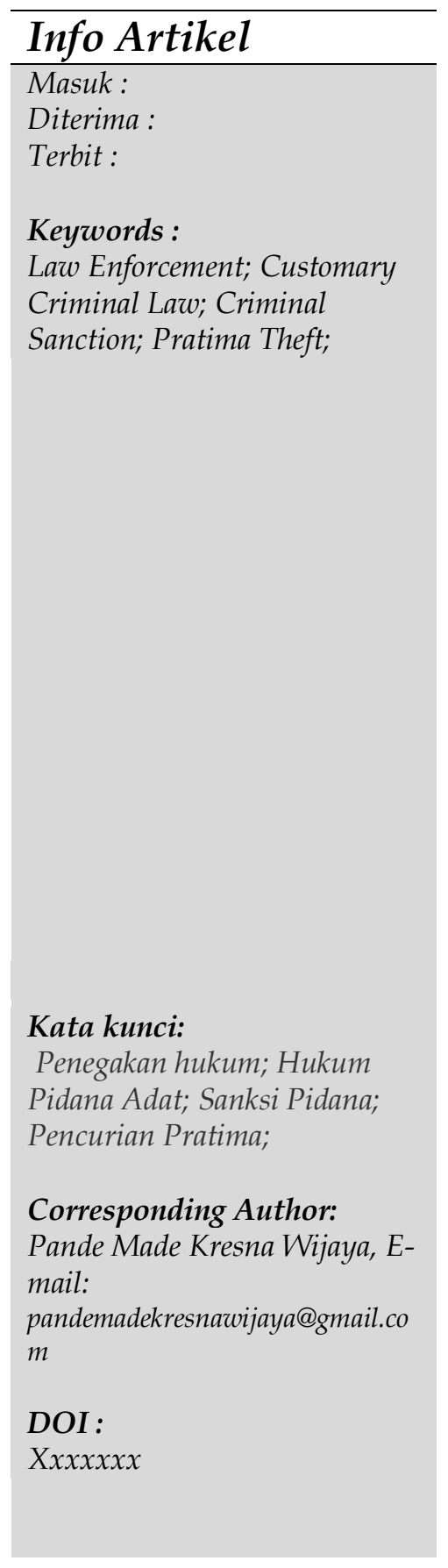

\begin{abstract}
The end of a law enforcement is giving sanctions to criminal offenders. In Bali there is a crime of theft where the object that is the object of a crime is Pratima (sacred object). In the Criminal Code it does not explicitly regulate customary sanctions, so the imposition of ordinary criminal sanctions against criminal offenders classified as customary criminal acts haven't been able to resolve the problem that occurred. The purpose of this journal is to analyse the related theft of pratima in the perspective of customary criminal law and the legal basis for customary sanctions. This study uses normative research methods. Then using the statute approach and conseptual approach after that discussed using legal argumentation techniques.

That pratima theft is more appropriately linked in the perspective of customary crimes, because the impact of the theft of pratima is not only on material losses but on immaterial losses which can disrupt the balance in society.

The application of customary sanctions for the settlement of criminal acts of pratima theft in Bali can be done because the existence of customary criminal law is still needed in Indonesia by linking the concepts of restorative justice, discretion and combined theory of punishment so that customary sanctions that can be imposed are fines for cleaning ceremonies.
\end{abstract}

\footnotetext{
Abstrak

Ujung dari suatu penegakan hukum adalah pemberian sanksi terhadap pelaku tindak pidana. Di Bali terdapat tindak pidana pencurian dimana benda yang menjadi objek tindak pidana adalah Pratima (Benda sakral). Ketentuan pada KUHP tidak mengatur secara jelas penjatuhan sanksi adat, oleh karena itu penjatuhan sanksi pidana biasa kepada pelaku tindak pidana yang tergolong tindak pidana adat terkadang belum bisa menyelesaikan permasalahan yang terjadi. Tujuan penelitian ini adalah untuk menganalisa terkait pencurian pratima dalam perspektif hukum pidana adat dan dasar hukum pemberian sanksi adat. Penelitian ini mempergunakan metode penelitian normatif. Kemudian menggunakan pendekatan perundangundangan dan pendekatan konseptual serta menggunakan teknik
} 
argumentasi hukum dalam pembahasannya.

Bahwa pencurian pratima lebih tepat dikaitkan dalam perspektif tindak pidana adat, karena dampak dari pencurian pratima tersebut tidak hanya pada kerugian materiil saja melainkan kerugian immateriil dimana dapat mengganggu keseimbangan di masyarakat.

Penerapan sanksi adat untuk penyelesaian tindak pidana pencurian pratima di Bali dapat dilakukan karena eksistensi hukum pidana adat masih dibutuhkan di Indonesia dengan mengaitkan konsep keadilan restorative, diskresi, dan teori pemidanaan gabungan sehingga sanksi adat yang dapat dijatuhkan adalah denda untuk upacara pembersihan.

\section{Pendahuluan}

Penegakan hukum adalah bagian penting dalam kehidupan bernegara. Penegakan hukum berkaitan dengan proses penegakan hukum meteriil dengan mengacu pada hukum formil dimana hasil dari penegakan hukum adalah pemberian sanksi kepada pelaku tindak pidana sebagaimana ketentutan perundang-undangan yang berlaku.

Negara Indonesia merupakan negara hukum (rechtsaat), yakni untuk mengatur tingkah laku masyarakat selalu berpedoman dengan aturan yang berlaku nasional atau hukum positif. Oleh karena itu, hukum positif diharapkan mampu mengatur kehidupan bermasyarakat dimana tujuannya untuk mencapai ketertiban umum. Sumber utama hukum positif adalah undang-undang, tetapi terdapat pula sumber hukum asli masyarakat Indonesia yang berasal dari sebuah kebiasaan, dimana hal ini lah yang melatarbelakangi terbentuknya suatu aturan yang berlaku pada masyarkat tertentu dan aturan itu disebut dengan hukum adat. Lilik Mulyadi memberikan pengertian hukum adat yakni hukum yang tercatat atau tidak tertulis yang berjiwa dan berkembang di masyarakat (living law), berisi kaedah-kaedah hukum dan memberikan rasa keadilan bagi masyarakat adat, serta diistilahkan hukum kebiasaan. ${ }^{2}$ Jadi hukum adat diartikan aturan hukum yang tercatat atau tidak tertulis berbeda halnya dengan aturan-aturan hukum lainnya tetapi hukum adat tercatat dan tetap diakui eksistensinya sepanjang masih diperlukan oleh masyarakat pada suatu daerah tertentu.

Bertitik tolak pada hukum pidana, dimana kenyataan tentang adanya hukum pidana adat ternyata tidak mudah diterima bahkan agar dapat dipraktekan dalam system peradilan pidana dianggap sangat sulit. Tidak lain dan tidak bukan yakni adanya asas legalitas yang menjadi tembok pembatas diberlakukannya hukum pidana tertulis dan tidak tertulis. Definisi dari Hukum pidana adat itu sendiri merupakan aturan tidak tertulis yang hidup dan berkembang pada masyarkat dimana mengatur tentang perbuatan yang bertentangan dengan keadilan dan kepatutan, oleh karena itu berdampak terhadap keharmonisan, keseimbangan masyarakat maka terjadi reaksi

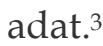

\footnotetext{
2 Mulyadi, L. (2013). Eksistensi Hukum Pidana Adat Di Indonesia: Pengkajian Asas, Norma, Teori, Praktik dan Prosedurnya. Jurnal Hukum dan Peradilan, 2(2), h.226.

$3 \quad$ Ibid., h.9
} 
Tindak pidana seperti pencurian belakangan ini begitu marak terjadi di daerah-daerah, tidak terkecuali di Bali. Bermacam-macam klasifikasi dalam tindak pidana pencurian mulai dari pencurian biasa, dengan kekerasan, dengan pemberatan seperti pencurian di malam hari. Tetapi yang menjadi menarik dari pencurian ketika apa yang menjadi objek kejahatan tidak lagi barang-barang bergerak yang umumnya biasa kita lihat melankan benda penting yang bagi masyarakat bali disakralkan. Di Provinsi Bali sangat banyak terdapat benda sakral atau benda yang disakralkan seperti contoh: patung-patung, keris, uang bolong (pis bolong), pratima, dan lainnya. Salah satu benda sakral yang menjadi objek pencuri adalah pratima. Dikutip dalam berita online pada beritabali.com yang berjudul yakni "Pencuri Pratima di 8 Pura Terungkap", dalam berita disebutkan pencurian pratima terjadi di kabupaten Karangasem, dimana pelaku mengaku telah melakukan aksinya di 8 pura lainnya. ${ }^{4}$

Benda sakral atau benda yang disakralkan merupakan benda yang dipercaya oleh masyarakat adat sebagai symbol Tuhan yang mana fungsinya sebagai media pemujaan kepada Tuhan serta dipercaya terdapat kekuatan gaib karena terdapat unsur mistis dalam proses penciptaannya. Pratima adalah benda sakral yang berbentuk patung dimana diyakini terdapat kekuatan mistis atau gaib serta sebagai simbol berkomunikasi dengan Tuhan. ${ }^{5}$ Bahwa terkadang benda sakral tersebut menyerupai benda biasa pada umumnya atau benda bergerak biasa, tetapi dikaitkan dengan masyarakat Bali, adanya berbagai pratima ini telah dilakukan prosesi-prosesi penyucian atau pengsakralan sesuai kepercayaan masyarakat adat yang beragama Hindu di Bali. Oleh sebab itu, berbagai pratima dapat disamakan dengan wadah berstananya Tuhan atau Ida Sang Hyang Widhi Wasa sebagai media pemujaan bagi umat Hindu.

Pencurian adalah kejahatan yang tercantum dalam Pasal 362, Pasal 363, dan Pasal 364 Kitab Undang-Undang Hukum Pidana (KUHP). Penegakan hukum terkait pencurian yang objeknya bukan pratima adalah hal biasa sehingga penerapan sanksi pidana umum dapat dilakukan, namun jika objeknya adalah pratima penerapan sanksi harus disesuaikan. Bagi masyarakat Bali tindakan tersebut tidak hanya merupakan pencurian pada umumnya namun dikategorikan tindak pidana adat. Bahwa menjadi perhatian penelitian ini yakni bagaimana perspektif hukum pidana adat memandang hal tersebut di atas, sehingga penerapan sanksi menjadi tepat dan memiliki kemanfaatan terkait delik-delik atat yang terjadi.

Penjatuhan sanksi merupakan hal yang penting dari bagian proses penegakan hukum, dimana ketepatan sanksi yang dijatuhkan akan memberikan kemanfaatan yang berujung pada keadilan bagi pihak yang terkait. Macam-macam sanksi yang termuat dalam Pasal 10 KUHP tidak mengatur secara tegas terkait penjatuhan sanksi adat. Oleh sebab itu, sanksi pidana biasa yang diberikan kepada pelaku tindak pidana terkadang belum bisa menyelesaikan permasalahan yang terjadi. Disisi lain, Undang-Undang Drt Nomor 1 Tahun 1951 yang berisikan aturan tentang kedudukan kekuasaan kehakiman untuk menjatuhkan sanksi mengacu pada hukum adat yang berlaku. Berdasarkan uraian latar belakang sebelumnya, maka sangat menarik untuk menulis jurnal ilmiah

4 URL : $\quad$ https://beritabali.com/read/2017/07/10/201707100010/Pencuri-Pratima-di-8-PuraTerungkap.html, diakses tanggal 25 April 2018

5 Sugiantari, A. P. W., \& Julianti, L. (2016). Peranan Awig-awig Desa Pakraman Dalam Mencegah Tindak Pidana Pencurian Benda Sakral Di Desa Pelaga Kecamatan Petang Kabupaten Badung. Jurnal Bakti Saraswati (JBS), 5(1), h. 61 
dengan judul "TINJAUAN YURIDIS PENJATUHAN SANKSI ADAT TERHADAP PELAKU PENCURIAN PRATIMA DI BALI."

Adapun rumusan masalah yang menjadi penting sebagai pembahasan jurnal ini yakni sebagai berikut:

1. Bagaimana perspektif dari hukum pidana adat terkait tindak pidana pencurian pratima yang terkadi di Bali?

2. Bagaimana pemberian sanksi adat kepada pelaku pencurian pratima di Bali?

Bahwa dapat penulis tegaskan penelitian dalam bentuk jurnal ini merupakan hasil pemikiran baru yang mana belum ditemui sebelumnya. Tetapi terdapat tulisan hasil penelitian sebelumnya yang menyerupai namun sejatinya memiliki pembahasan berbeda dimana penelitian tersebut dijadikan sebagai pembanding orisinalitas terhadap jurnal ini, sebagai berikut:

1. Penelitian berbentuk jurnal ilmiah yang ditulis oleh Bobi Handoko dengan judul "Penerapan Sanksi Pidana Adat Terhadap Pelaku Zina Di Wilayah Kenagarian Garagahan Kecamatan Lubuk Basung Kabupaten Agam". Adapun permasalahan yang diangkat dalam Jurnal ini adalah pertama, terkait penerapan sanksi adat terhadap pelaku perzinahan. Kedua, terkait hambatan penerapan sanksi adat terhadap pelaku perzinahan dan ketiga, terkait langkah untuk mengatasi hambatan penerapan sanksi adat terhadap pelaku perzinahan. Perbedaannya dengan penelitian milik penulis yakni dalam penelitian ini menggunakan jenis penelitian empiris terlihat dari judul dan rumusan masalahnya sedangkan penelitian penulis mempergunakan jenis penelitian normatif. Antara Penelitian ini dan penelitian penulis menggunakan objek tindak pidana yang berbeda.

2. Penelitian dalam bentuk jurnal oleh A.A. Putu Wiwik Sugiantari dan Lis Julianti dengan Judul "Peranan Awig-Awig Desa Pekraman Dalam Mencegah Tindak Pidana Pencurian Benda Sakral di Desa Pelaga Kecamatan Petang Kabupaten Badung". Beberapa permasalahan yang akan dibahas adalah pertama, terkait peran desa pakraman dalam melindungi pencurian benda sakral dan kedua, terkait bentuk perlindungan hukum dari desa pakraman terkait benda sakral guna menghindari pencurian kembali. Perbedaannya dengan penelitian yang penulis buat yakni penggunaan metode penelitian dimana penelitian ini mempergunkan jenis penelitian empiris sedangkan penelitian penulis menggunakan jenis penelitian normatif. Penelitian ini lebih memfokuskan pada sisi peran desa pekraman dan bentuk perlindungan hukum sedangkan penelitian penulis memfokuskan pada bagaimana penjatuhan sanksi adat bagi pelaku pencurian.

Penelitian dalam bentuk jurnal ini memiliki tujuan untuk memberikan penjelasan mengenai perspektif dari hukum pidana adat terkait tindak pidana pencurian pratima yang terjadi di Bali dan menganalisa terkait dasar hukum menerapkan sanksi pidana adat dalam suatu tindak pidana pencurian pratima yang bisa digolongkan sebagai delik adat.

\section{Metode Penelitian}

Metode penelitian yang dimaksud tentu berkaitan dengan penelitian hukum. Penelitian hukum merupakan cara untuk menemukan kembali dengan cermat dan teliti terhadap data hukum atau bahan hukum guna menyelesaikan masalah-masalah 
hukum. ${ }^{6}$. Tujuan dari suatu penelitian hukum merupakan bentuk usaha untuk mencari, menganalisa, mengkaji kebenaran ilmu pengetahuan terkait ilmu hukum. Yang terpenting dalam menyusun suatu penelitian adalah bagaimana penulis bisa bertanggungjawab atas kebenaran dan keasliannya.

Bahwa jurnal ini berpedoman pada metode penelitian hukum normatif. Penelitian hukum normatif digunakan untuk mengkaji peraturan perundang-undangan terkait permasaahan yang akan di bahas. Jurnal ini menggunakan 2 sumber bahan hukum yakni primer dan sekunder. Peraturan perundang-undangan yang merupakan hukum positif di Indonesia merupakan bahan hukum primer dan berbagai buku hukum, berbagai jurnal ilmiah serta buku hukum yang berhubungan terhadap masalah yang akan dikaji disebut bahan hukum sekunder.

Jenis pendekatan yang digunakan dalam pembahasan jurnal ini yakni pendekatan perundang-undangan dan pendekatan konseptual. Pendekatan perundang-undangan dimaksudkan untuk menelusuri aturan-aturan hukum yang berlaku sesuai dengan permasalahan jurnal. Kemudian pendekatan konseptual dilakukan untuk menganalisis teori hukum, konsep hukum, ataupun asas-asas hukum berkaitan dengan pemberian sanksi. Serta jurnal ini menggunakan teknik argumentasi dalam pembahasan yakni argumentasi dilakukan oleh penulis untuk memberikan penilaian terkait perbuatan hukum didasarkan pada alasan0alasan yang bersifat penalaran hukum.

\section{Hasil Dan Pembahasan}

\subsection{Perspektif Hukum Pidana Adat Terkait Tindak Pidana Pencurian Pratima Yang Terjadi di Bali}

Ketentuan hukum pidana umum yang termuat dalam Kitab Undang-Undang Hukum Pidana (KUHP) yang berlaku di Indonesia merupakan hasil kodifikasi hukum Belanda dimana pada saat ini diberlakuan berdasarkan asas konkordansi. KUHP merupakan sumber dari hukum pidana Indonesia sehingga tetap diberlakukan asalkan tidak diatur lain oleh aturan-aturan hukum di luar KUHP. Asas hukum yang paling mendasari KUHP adalah asas legalitas. Pasal 1 ayat (1) KUHP mengatur tentang asas legalitas yang inti pokoknya menerangkan bahwa perbuatan seseorang bisa dijatuhkan pidana jika telah diatur sebelumnya oleh peraturan perundang-undangan.

Asas legalitas bukanlah hal mutlak yang ada dalam hukum pidana, eksistensi hukum pidana adat sebagai aturan yang bersumber, hidup serta berkembang di dalam masyarakat harus tetap diberikan kedudukannya sebagai salah satu sumber hukum. Hukum pidana adat adalah cerminan asli dari peradaban bangsa Indonesia yang pernah menerapkannya serta tersebar di berbagai daerah dengan ditandai oleh kesatuan masyarakat hukum adat. ${ }^{7}$ Peraturan-peraturan terkait hukum pidana adat masih diikuti dan diterapkan dalam masyarakat adat di beberapa daerah Indonesia. Ketidakpatuhan terhadap aturan hukum pidana adat dapat

6 Pasek Diantha, I.M., (2017), Metode Penelitian Hukum Normatif Dalam Justifikasi Teori Hukum, Jakarta : Prenada Media Group, h. 1

7 Abdullah, R. H. (2015). Urgensi Hukum Adat dalam Pembaharuan Hukum Pidana Nasional. Fiat Justisia, 9(2)., h. 178 
menimbulkan reaksi adat atau mengganggu keseimbangan kosmis masyarakat sehingga harus diberikan sanksi adat guna memulihkan keseimbangan masyarakat adat.

Asas-asas hukum adat dapat dilihat dari sifat hukum adat itu sendiri yaitu: ${ }^{8}$

a. Asas Religiomagis, hukum adat mempercayai atas kekuatan gaib dan tidak berdasarkan logika serta kenyataan semata.

b. Asas komunal, hukum adat pada dasarnya mengatur kepentingan bersama dimana kaedah-kaedahnya kebanyakan berlaku umum.

c. Asas kontan, menunjukan bahwa transaksi dalam hukum adat dikehendaki secara kontan, sehingga prestasi atau kontraprestasi terlaksana serentak.

d. Asas konkret, menunjukan bahwa sahnya suatu hubungan hukum menurut hukum adat, apabila perbuatan hukum itu terjadi secara nyata.

Sumber utama hukum adat adalah kebiasaan yang mana bentuknya tidak tertulis melainkan tercatat. Pada umumnya hukum adat tersebut tidak memiliki klasifikasi khusus tetapi sering diistilahkan hukum harta benda dan hukum kekeluargaan serta karena terdapat dellik adat maka diatur oleh hukum pelanggaran adat atau hukum pidana adat. ${ }^{9}$ Penentuan delik adat tidak dipengaruhi oleh asas legalitas sebagaimana dikenal dalam hukum pidana nasional yakni KUHP. Hukum asli dalam masyarakat adat merupakan hukum pidana adat yang tidak tertulis layaknya aturan-aturan hukum lainnya namun mengandung unsur yang bersinggungan dengan adat istiadat atau agama, ditaati dan diikuti oleh masyarakat secara terus menerus. ${ }^{10}$ Lebih lanjut, penjelasan Bushar Muhammad sebagaimana dikutip dan dijelaskan oleh I Made Widnyana bahwa delik adat diartikan sebagai perbuatan seseorang atau kumpulan beberapa orang, bersifat menggangu, menyinggung dan/atau mengancam keharmonisan atau keseimbangan hidup masyarakat baik bersifat imateriil maupun material, sehingga tindakan tersebut bisa mengakibatkan suatu reaksi-reaksi dalam masyarakat adat. ${ }^{11}$

Sebagaimana paparan sebelumnya, yakni pratima merupakan benda sakral atau benda yang dipercaya bagi masyarakat umat hindu di Bali sebagai simbol dalam memuja Tuhan sehingga pencurian terhadap pratima bukan pencurian pada umumnya terhadap benda-benda lainnya seperti kendaraan bermotor, telepon dan lain-lain. Pencurian pratima tentu memiliki konsekuensi kerugian berbeda, dimana kerugian immateriil lebih besar daripada materiil.

Jika melihat dari delik adat, pada pokoknya terdapat beberapa unsur-unsur penting delik tersebut yaitu: (1) adanya perbuatan baik dilakukan oleh perorangan, sebuah kelompok ataupun dilakukan oleh pranata adat sendiri; (2) perbuatan yang dilakukan melanggar norma-norma pada hukum adat; (3) perbuatan tersebut berdampak lebih dari sekedar tindak pidana yakni mengganggu keseimbangan kosmis dalam masyarakat; (4) perbuatan tersebut berdampak terhadap reaksi dari masyarakat sehingga dapat diberikan sanksi adat. ${ }^{12}$ Oleh karena itu, dikaitkan

8 Subari, H.A.S., dkk., (2010), Pokok-Pokok Hukum Adat, Palembang: Penerbit Universitas Sriwijaya, h. 1112.

9 Kurniawan, F. (2016). Hukum Pidana Adat sebagai Sumber Pembaharuan Hukum Pidana Nasional. EDUKA Jurnal Pendidikan, Hukum dan Bisnis, 2(2), h.11.

10 Widnyana, I.M., (2013), Hukum Pidana Adat Dalam Pembaharuan Hukum Pidana, Jakarta : PT. Fikahati Aneska, h. 111

11 Ibid., h. 116

12 Ibid., h. 112 
dengan pencurian pratima hukum pidana adat memilki pandangan yang berbeda terhadap pencurian pratima, karena objek atau barang yang dicuri adalah benda yang disucikan oleh umat Hindu.

Dari uraian di atas, bahwa pencurian pratima lebih tepat dikaitkan dalam perspektif tindak pidana adat, karena dampak dari pencurian pratima tersebut tidak hanya pada kerugian materiil saja melainkan kerugian immateriil dimana dapat mengganggu keseimbangan di masyarakat serta bersinggungan dengan asas-asas hukum adat. Oleh masyarakat Bali jelas akan mengganggu yang namanya hubungan antara manusia dengan Tuhan sebagaimana Bali mengenal adanya ajaran Tri Hita Karana. Terkait sanksi-sanksi yang tepat dibelikan kepada pelaku tindak pidana akan lebih jelas di paparkan dalam pembahasan berikutnya.

\subsection{Pemberian Sanksi Adat Kepada Pelaku Pencurian Pratima Yang Terjadi di Bali}

Pencurian pratima yang terjadi di Bali yang lebih tepat masuk dalam perspektif tindak pidana adat, sehingga penerapan sanksi sudah sangat tepat jika disesuaikan dengan sanksi-sanksi yang terdapat dalam tindak pidana adat. Penjatuhan sanksi pidana dalam KUHP dirasa tidak tepat karena dalam pencurian pratima tidak dilihat dari kerugian mareriil saja melainkan kerugian immateriil. Pertanyaan selanjutnya, apakah bisa sanksi pidana adat dijatuhkan kepada pelaku pencurian pratima di Bali.

Ada beberapa kasus di daerah Minangkabau telah diadili oleh Kerapatan Adat Nagari (KAN), yaitu tahun 1998, terjadi di KAN Talago Gunung Kecamatan Baringin memberikan putusan bahwa ada orang yang bernama Jamalis terbukti berbuat delik adat yakni sumbang-salah dikarenakan satu rumah dengan seorang perempuan yang tidak istrinya, berikutnya pada tahun 2004 berlokasi di KAN Air Tabit Kecamatan Payakumbuh Timur menjatuhkan hukuman adat kepada A.M Dt Panduko Sati dikarenakan telah melakukan delik adat yakni delik dago-dagi terhadap kasus penghancuran rumah adat.13

Dalam membahas pertanyaan di atas, haruslah dilihat terlebih dahulu mengenai eksistensi peradilan pidana adat dengan mengacu pada aturan-aturan hukum yang ada. Jika melihat pada aturan yang berlaku di Indonesia yakni hukum positif, bahwa terdapat beberapa aturan-aturan hukum yang mana secara explisit maupun implisit mengatur tentang pemberlakuan hukum pidana adat dalam praktek peradilan pidana antara lain:

1. Termuat dalam Undang-Undang Dasar Negara Republik Indonesia Tahun 1945 yakni Pasal 18B Ayat (2);

2. Dalam Undang-Undang Drt Nomor 1 Tahun 1951 tentang Tindakan-tindakan Sementara untuk Menyelenggarakan Kesatuan Susunan, Kekuasaan, dan Acara Pengadilan-pengadilan Sipil;

3. Undang-Undang Nomor 48 Tahun 2009 tentang Kekuasaan Kehakiman. (UU Kekuasaan Kehakiman)

13 Danil, E. (2012). Konstitusionalitas Penerapan Hukum Adat dalam Penyelesaian Perkara Pidana. Jurnal Konstitusi, 9(3),, h.586 
Konstitusi menjadi dasar terhadap berlakunya hukum adat di Indonesia, tercantum dalam Pasal 18 B ayat (2) yang pada intinya menyebutkan bahwa negara sangat menghormati masyarakat adat serta hak tradisionalnya sejauh masih hidup namun tetap harus sesuai dengan prinsip Negara Kesatuan Republik Indonesia (NKRI).

Pembuat aturan hukum sudah memberikan legalitas guna memberlakukan hukum pidana adat ke dalam praktek sistem peradilan pidana mengacu pada ketentuan Undang-Undang Nomor 1 Drt Tahun 1951 yakni Pasal 5 (3) sub b. Inti dari ketentuan tersebut, bahwa terhadap seseorang yang diputus bersalah berdasarkan hukum adat, tetapi hukumannya tidak dijalani, oleh karena itu perbuatannya harus disamakan dengan tindak pidana dan dapat dijatuhkan sanksi kurang dari 3 bulan penjara berdasarkan KUHP. Sehingga secara tidak langsung, adanya pengakuan terhadap delik adat yang terjadi pada masyarakat adat.

Kemudian, terdapat aturan-aturan terkait hukum adat yang tercantum di dalam perkembangan Undang-Undang Kekuasaan Kehakiman, yakni dari awal UndangUndang Nomor 14 Tahun 1970 tentang Ketentuan-Ketentuan Pokok Kekuasaan Kehakiman, hingga Undang-Undang Kekuasaan Kehakiman paling terbaru. Pasal 5 ayat (1) UU Kekuasaan Kehakiman pada intinya mengatur bahwa para hakim dalam persidangan harus mengetahui, menerapkan serta mendalami nilai-nilai hukum dan rasa keadilan dalam masyarakat. Dari beberapa ketentuan tersebut telah diakui eksistensi hukum adat dan penerapan sanksi adat terhadap tindak pidana adat. Tetapi bagaimana dampaknya terhadap penegakan melalui hukum nasional tentu akan menjadi tumpang tindih kewenangan dalam penegakan hukum.

Keberadaan Hukum pidana adat di beberapa daerah Indonesia masih diterapkan dalam penegakan hukum, termasuk di Bali. Penerapan sanksi jika mengacu pada hukum asli masyarakat adat yakni hukum pidana adat akan lebih memiliki nilai kemanfaatan dibandingkan penerapan sanksi yang terdapat dalam KUHP jika tindak pidananya bisa termasuk dalam delik adat sehingga bisa mengembalikan keseimbangan atau keharmonisan yang terganggu oleh terjadinya suatu tindak pidana adat. Namun demikian, persoalan yang akan muncul apakah mungkin di luar proses peradilan pidana diberlakukannya hukum adat guna mengadili perkara-perkara pidana adat. Kemudian bagaimana jika mengadili kasus-kasus delik adat melalui lembaga adat, seperti mengadakan paruman-paruman di Desa Pakraman Bali.

Tentu tidak serta-merta dapat mengaktualisasi penerapan sanksi adat Cuma berdasarkan aturan-aturan sebagaimana disebut di atas, karena dalam hukum pidana telah dibentuk hukum formilnya yakni Kitab Undang-Undang Hukum Acara Pidana (KUHAP) dan Undang-Undang 8 Tahun 1981 tentang Hukum Acara Pidana yang memiliki fungsi sebagai pedoman penegakan hukum nasional. Dengan demikian bahwa eksistensi peradilan adat masih selalu dipertanyakan keberadaannya. Karena keberadaan peradilan adat begitu urgensi bagi masyarakat adat sehingga harus ditunjang oleh aturan-aturan yang lebih formal.

Penegakan hukum terhadap tindak pidana adat akan lebih baik menggunakan lembaga adat karena jika tetap pada jalur peradilan umum tidak jarang adanya rasa kurang puas terhadap putusan pengadilan formal. Penjatuhan sanksi melalui putusan pengadilan tidak akan mampu mengembalikan keseimbangan atau 
harmonisasi hubungan Tuhan dengan manusia sebagai akibat dilakukannya delik adat. Maka sebab itu, perspektif hukum pidana adat harus bisa ditonjolkan dalam kasus-kasus tertentu yang bersinggungan langsung dengan masyarakat adat dan dicarikan pemecahannya secara akademik melalui konsep-konsep hukum tatau teori-teori hukum sehingga lembaga adat dapat mengadili pelanggaranpelanggaran hukum pidana adat.

Pertama yang penting adalah melihat aturan-aturan adat yang terdapat dalam masing-masing desat adat, di Bali aturan tersebut di kenal dengan nama awig-awig. Bahwa Awig-awig dibentuk oleh masyarakat adat dengan memuat aturan adat yang memiliki tujuan dalam menjaga atau mewujudkan keharmonisan antara hubungan manusia dengan Tuhan (perahyangan), lingkungan (palemahan) dan manusia itu sendiri (pawongan). ${ }^{14}$ Dalam kehidupan masyarakat Bali, awig-awig digunakan untuk mengatur kehidupan masyarakat desa adat agar harmonis. Awig-awig bisa digunakan sebagai pedoman awal dalam menerapkan sanksi adat terhadap tindak pidana pencurian pratima.

Kedua, untuk memperkuat argumentasi mengenai bahwa peradilan adat masih diperlukan dalam penanganan-penanganan terhadap tindak pidana adat, terdapat teori keadilan restoratif atau restorative justice. Memang saat ini teori tersebut baru secara explisit termuat dalam Undang-Undang Sistem Peradilan Pidana Anak Tahun 2012, namun teori di atas selayaknya bisa diterapkan lebih luas dengan bersifat kasuistis. Teori Keadilan Restoratif tidak semata-mata dapat diterapkan dalam tindak pidana ringan tetapi juga diterapkan dalam tindak pidana umum biasa.

Menurut kriminologi asal Inggris yakni Tony F. Marshall dalam tulisannya "Restorative Justice an Overview" yang dikutip Marlina menyebutkan:15

"Restorative Justice is a process whereby all the parties with a stake in a particular offence come together to resolve collectively how to deal with the aftermath of the offence and its implication for the future". Pada intinya memiliki pengertian bahwa keadilan restoratif merupakan proses secara bersama-sama seluruh pihak yang terkait untuk menyelesaikan permasalahan serta memperbaiki akibat dari permasalahan demi kepentingan bersama..

Pemikiran dari teori di atas sangatlah tepat diterapkan dalam penerapan sanksi adat dalam tindak pidana adat. Konsep tersebut sangatlah tepat untuk merespons perkembangan sistem peradilan pidana yang selama ini selalu mengesampingkan kepentingan korban dan masyarakat dalam mekanisme system peradilan pidana. ${ }^{16}$ Jadi pada intinya, penegakan hukum dengan menggunakan konsep keadilan restoratif akan bisa melindungi kepentingan korban dan juga pelaku. Konsep keadilan restoratif memberikan pendekatan yang jauh berbeda dengan keadilan retributif yang selama ini menjadi konsep hukum pidana pada umumnya. Keadilan restoratif adalah mengutamakan jalur musyawarah dan mediasi untuk mengembalikan keadaan dimana sebelum terjadinya suatu tindak pidana dengan

14 Sugiantari, A. P. W., \& Julianti, L., Op. Cit., h. 66

15 Marlina, (2010), Pengantar Konsep Diversi dan Restoratif Justice dalam Hukum Pidana Medan : USU Press, h. 28.

16 Zulfa, E. A., (2011), Pergeseran Paradigma Pemidanaan, Bandung: Lubuk Agung, h. 65. 
melibatkan seluruh komponen mulai dari pelaku, korban, lembaga masyarakat dan penegak hukum.

Penegakan hukum terkait tindak pidana adat akan lebih efektif dan sesuai dengan konsep keadilan restoratif. Tetapi memang eksistensi lembaga adat dalam menyelesaikan perkara pidana adata di Indonesia mulai ditinggalkan. Pada kenyataannya, hukum adat diyakini mampu menyelesaikan reaksi sosial yang terjadi pada masyarakat serta dinilai dapat memberikan rasa keadilan dalam masyarakat. Hukum pidana adat selalu didasarkan atas sifat kolektif yang ada di masyarkat karena yang dicari adalah hubungan harmonis antar masyarakat adat sehingga penyelesaian dengan jalan damai menjadi fokus utamanya. Tujuan hukum pidana adat tidak menitikberatkan pada suatu pembalasan semata melainkan sanksi yang dijatuhkan akan memiliki manfaat guna memulihkan kembali keadaan setelah adanya tindak pidana kepada keadaan sebelum terjadinya tindak pidana.

Menurut penulis, penerapan keadilan restoratif seharusnya mulai dari tingkatan paling awal yakni pada tahap laporan atau penyidikan yang dilakukan oleh kepolisian, karena itu merupakan input perkara pidana ke dalam sistem peradilan pidana. Tetapi masih ada penegak hukum lainnya yang memiliki peran yang sama pentingnya yakni kejaksaan dan pengadilan harus mendukung penerapan konsep keadilan restoratif. Lembaga kepolisian dan lembaga kejaksaan memiliki diskresinya masing-masing sebagaimana di atur dalam undang-undang. Diskresi merupakan bagian dari kebijakan hukum pidana dimana kebijakan dimaksudkan untuk menanggulangi kejahatan. Keadilan restoratif sering dilakukan pihak kepolisian baik secara sadar atau tidak melalui diskresinya yaitu terhadap kasuskasus kecelakaan lalu lintas. Diskresi penting dilakukan jika terdapat aturan-aturan hukum yang masih perlu pengaturan lebih lanjut disebabkan perkembangan masyarakat yang begitu dinamis. Berdasarkan atas kewenangan diskresi yang dimiliki para penegak hukum, upaya pengalihan pemeriksaan kasus-kasus yang berkaitan dengan delik adat dapat dilakukan di luar proses peradilan formal dengan maksud diselesaikan melalui lembaga adat menggunakan cara musyawarah.

Sanksi adat di Bali begitu beragam, mulai yang paling ringan hingga berat yakni merarung (ditenggelamkan). Penerapan sanksi-sanksi adat tidaklah sama pada tiaptiap desa adat di Bali, serta sanksi-sanksi adat tidaklah bersifat statis namun selalu mengikuti perkembangan masyarakat dan perkembangan hukum tertulis sebagai contoh sanksi adat mapulang ke pasih sudah tidak lagi diterapkan karena dianggap tidak manusiawi. ${ }^{17}$ Kemudian terkait sanksi adat yang dapat dijatuhkan yakni (a). Diadakan upacara pembersihan (penyucian), di mana segala biaya biasanya ditanggung oleh si pelaku; (b). danda (denda berupa uang); dan (c) juga dipecat sebagai anggota masyarakat adat. 18

Pemberian sanksi adat kepada pelaku pencurian pratima selain didasarkan atas teori keadilan restoratif dan diskresi penegak hukum yang berkaitan dengan kebijakan hukum pidana juga dapat didasarkan atas teori pemidanaan gabungan. Teori pemidanaan ini adalah gabungan dari teori absolut dan teori relatif yang

17 Lailah, I., (2014), Sanksi Bagi Pelaku Tindak Pidana Kesusilaan (Lokika Sanggraha) Pada Masyarakat Bali Perspektif Hukum Pidana Islam, Universitas Islam Negeri Syarif Hidayatullah Jakarta, h. 19.

18 Widnyana, I. M., Op. Cit., h. 25 
mengajarkan bahwa penjatuhan hukuman dimaksud untuk mempertahankan tertib hukum dalam masyarakat dan memperbaiki pribadi si penjahat. ${ }^{19}$ Menurut Pellegrino sebagaimana dikutip oleh I Made Widnyana, yang merupakan penggagas teori gabungan ini menyatakan bahwa pembalasan sebagai asas dari pidana dimana beratnya suatu pidana tidak boleh melampaui pembalasan yang adil, tetapi pidana mempunyai berbagai pengaruh untuk perbaikan sesuatu yang rusak dalam masyarakat dan prevensi general. ${ }^{20}$

Eksistensi sanksi adat diharapkan bisa berperan dan berfungsi sebagai penyeimbang antara dunia lahir (skala) dan dunia gaib (niskala). Sudah sepatutnya penjatuhan sanksi adat dapat dilakuakn oleh masyarakat adat, karena hal tersebut sebagai upaya-upaya untuk menanggulangi pelanggaran adat, dimana contoh sanksi yang dapat diterapkan adalah upacara pebersihan desa yang bertujuan mengembalikan keseimbangan hubungan manusia dengan Tuhan yang telah terganggu. ${ }^{21}$ Hukum tidak akan bisa memberikan rasa keadilan yang sama terhadap manusia dengan mematok antara perbuatan benar dan perbuatan salah secara sempurna sehingga ada ungkapan yakni semakin hebat hukum bekerja justru lebih menimbulkan ketidakadilan diistilahkan dengan "summum ius summa iniuria".22 Dengan pemberian sanksi yang tepat terhadap pencurian pratima bisa membuat keseimbangan masyarakat menjadi sediakalanya.

\section{Kesimpulan}

Bahwa pencurian pratima lebih tepat dikaitkan dalam perspektif tindak pidana adat, karena dampak dari kejahtan tersebut tidak hanya pada kerugian materiil saja melainkan kerugian immateriil dimana dapat mengganggu keseimbangan di masyarakat serta bersinggungan dengan asas-asas hukum adat.

Bahwa pemberian sanksi adat kepada pelaku pencurian pratima di Bali dapat diterapkan karena secara eksistensi hukum pidana adat masih diakui dalam hukum pidana Indonesia melalui UUD NRI Tahun 1945, UU Drt Nomor 1 Tahun 1951 dan UU Kekuasaan Kehakiman Nomor 48 Tahun 2009, dengan mengacu pada konsep keadilan restoratif dan kebijakan pidana berupa diskresi serta teori pemidanaan gabungan. Sanksi adat yang dapat dijatuhkan yakni (a). Diadakan upacara pembersihan (penyucian), di mana segala biaya biasanya ditanggung oleh si pelaku; (b). danda (denda berupa uang); dan (c) juga dipecat sebagai anggota masyarakat adat.

\section{Daftar Pustaka / Daftar Referensi}

\section{Buku :}

Marlina, (2010), Pengantar Konsep Diversi dan Restoratif Justice dalam Hukum Pidana Medan : USU Press.

Pasek Diantha, I.M., (2017), Metode Penelitian Hukum Normatif Dalam Justifikasi Teori Hukum, Jakarta : Prenada Media Group.

19 Widnyana, I.M., Op. Cit., h. 88.

20 Widnyana, I.M., Loc. Cit..

21 Mahendra Putra, Nyoman Roy, (2009), Penyelesaian Pelanggaran Adat Di Kecamatan Busungbiu Kabupaten Buleleng Menurut Hukum Adat Bali, Universitas Diponegoro, h. 21

22 Manarisip, M. (2013). Eksistensi Pidana Adat dalam Hukum Nasional. Lex Crimen, 1(4), h. 39. 
Subari, H.A.S., dkk., (2010), Pokok-Pokok Hukum Adat, Palembang: Penerbit Universitas Sriwijaya.

Widnyana, I.M., (2013), Hukum Pidana Adat Dalam Pembaharuan Hukum Pidana, Jakarta : PT. Fikahati Aneska.

Zulfa, E. A., (2011), Pergeseran Paradigma Pemidanaan, Bandung: Lubuk Agung.

Jurnal :

Abdullah, R. H. (2015). Urgensi Hukum Adat dalam Pembaharuan Hukum Pidana Nasional. Fiat Justisia, 9(2).

Danil, E. (2012). Konstitusionalitas Penerapan Hukum Adat dalam Penyelesaian Perkara Pidana. Jurnal Konstitusi, 9(3).

Kurniawan, F. (2016). Hukum Pidana Adat sebagai Sumber Pembaharuan Hukum Pidana Nasional. EDUKA Jurnal Pendidikan, Hukum dan Bisnis, 2(2).

Lailah, I., (2014), Sanksi Bagi Pelaku Tindak Pidana Kesusilaan (Lokika Sanggraha) Pada Masyarakat Bali Perspektif Hukum Pidana Islam, Universitas Islam Negeri Syarif Hidayatullah Jakarta.

Manarisip, M. (2013). Eksistensi Pidana Adat dalam Hukum Nasional. Lex Crimen, 1(4).

Mulyadi, L. (2013). Eksistensi Hukum Pidana Adat Di Indonesia: Pengkajian Asas, Norma, Teori, Praktik dan Prosedurnya. Jurnal Hukum dan Peradilan, 2(2).

Sugiantari, A. P. W., \& Julianti, L. (2016). Peranan Awig-awig Desa Pakraman Dalam Mencegah Tindak Pidana Pencurian Benda Sakral Di Desa Pelaga Kecamatan Petang Kabupaten Badung. Jurnal Bakti Saraswati (JBS), 5(1).

Suwandi, A., Zanibar, Z., \& Achmad, R. (2017). Eksistensi Hukum Adat Terhadap Hukum Pidana. Legalitas: Jurnal Hukum, 1(3).

Tesis atau Disertasi :

Mahendra Putra, Nyoman Roy, (2009), Penyelesaian Pelanggaran Adat Di Kecamatan Busungbiu Kabupaten Buleleng Menurut Hukum Adat Bali, Universitas Diponegoro.

Internet :

URL : https://beritabali.com/read/2017/07/10/201707100010/Pencuri-Pratima-di-8Pura-Terungkap.html, diakses tanggal 25 April 2018.

\section{Peraturan Perundang-Undangan :}

Undang-Undang Dasar Negara Republik Indonesia Tahun 1945.

Kitab Undang-Undang Hukum Pidana.

Undang-Undang Darurat Nomor 1 Tahun 1951 Tentang tentang Tindakan-Tindakan Sementara Untuk Menyelenggarakan Kesatuan Susunan Kekuasaan dan Acara Peradilan-Peradilan Sipil, Lembaran Negara Dan Tambahan Lembaran Negara Tahun 1951.

Undang-Undang Nomor 48 Tahun 2009 Tentang Kekuasaan Kehakiman, Lembaran Negara Republik Indonesia Tahun 2009 Nomor 157 Dan Tambahan Lembaran Negara Republik Indonesia Nomor 5076. 